\title{
Endocrine disrupting effects of 4-nonylphenol on plasma vitellogenin, reproductive system and histology in koi carp (Cyprinus carpio)
}

\author{
Parisa Amaninejad - Homayoun Hosseinzadeh Sahafi - Mehdi Soltani (i) \\ Seyed Pezhman Hosseini Shekarabi (i)
}

Received: 30 March 2018/Accepted: 16 August 2018/Published online: 23 August 2018

(C) The Author(s) 2018

\begin{abstract}
This study aimed to assess the effect of 4-nonylphenol (4-NP), a ubiquitous aquatic micro-chemical pollutant substance on some on some reproductive parameters and histology in koi carp. Fish were intraperitoneally subjected to ascending doses of 4-NP at 10, 50 and $100 \mu \mathrm{g} / \mathrm{g}$ body weight (BW) on days 7, 14 and 21 after the initiation of the experiment. Also, one group was treated with $17 \beta$-estradiol (E2) at $2 \mu \mathrm{g} / \mathrm{g}$ BW, positive control group (C2) received the vehicle (50 $\mu \mathrm{L}$ of coconut oil $+50 \mu \mathrm{L}$ Ethanol) per fish and a negative control group (C1) was considered without injection. The results showed that 4-NP induced significantly an increase in E2, progesterone, and plasma vitellogenin at $50 \mu \mathrm{g} / \mathrm{g}$ in both male and female, while level of testosterone significantly decreased in the treated fish compared to control fish $(P<0.05)$. Conversely, the levels of these parameters at the higher concentration of 4-NP $(100 \mu \mathrm{g} / \mathrm{g})$ were significantly reduced compared to control one $(P<0.05)$. Also, some sever histopathological changes were observed in ovary, testicular and liver of treated fish, reflecting fish sensitivity to 4-NP at higher doses. This study showed that 4-NP has an estrogenic potency in the sexual development, hepatotoxicity and gonado-toxicity of koi carp.
\end{abstract}

Keywords Nonylphenol $\cdot$ Reproductive system $\cdot$ Vitellogenin $\cdot$ Histopathology $\cdot$ Koi carp

\section{Introduction}

Both natural and synthetic endocrine disrupting chemicals (EDCs) are able to cause many disorders and interferences with animal endogenous hormones systems including adverse effects on hormone receptors, normal hormone synthesis and secretion (Maradonna and Carnevali 2007; Zaccaroni et al. 2009). Huge volume of EDCs is released to the global environment influencing serious potential hazardous effects on

\footnotetext{
P. Amaninejad $(\bowtie) \cdot$ S. P. Hosseini Shekarabi

Department of Fisheries Science, Science and Research Branch, Islamic Azad University, Tehran, Iran

e-mail: parisaamaninejad@yahoo.com

H. Hosseinzadeh Sahafi

Iranian Fisheries Science Research Institute Agriculture Research, Education and Extension Organization, Tehran, Iran

M. Soltani

Department of Aquatic Animal Health, Faculty of Veterinary Medicine, University of Tehran, Tehran, Iran

Present Address:

M. Soltani

Freshwater Fish Group and Fish Health Unit, School of Veterinary and Life Science, Murdoch University, Perth, Australia
} 
animal health condition and reproductive functions via the food chain and contaminated water resources (Vos et al. 2000). Among classes of EDCs, 4-nonylphenol (4-NP) is considered as an estrogen-like and antiandrogenic chemical and captured the attention of many investigators to its effect on the animal reproductive system (Sayed et al. 2012). 4-NP is an ultimate degradation product of nonylphenol ethoxylates (NPEs) and both are the most widely used members of alkylphenol and alkylphenol ethoxylate family of non-ionic detergents used in a wide variety of industrial applications including pesticides, spermicides, paints, wetting agents, textiles, plastics and paper products (John et al. 2000; Uguz et al. 2003; Sone et al. 2004; Rivero et al. 2008).

Reproduction in vertebrates such as fish is mainly regulated by the endocrine system primarily affected along the hypothalamic-pituitary-gonadal (HPG) axis via neural and hormonal feedback (Yaron et al. 2003; Choi et al. 2010). The role of $17 \beta$-estradiol (E2) as a neuroendocrine feedback control on the HPG axis has been shown in fish reproductive process (Yadetie et al. 1999). 4-NP has the ability to compete with E2 receptor binding and exerts an estrogen-like transcriptional activity on expression of estrogen receptor gene in liver, gill, pituitary and brain (Christensen et al. 1999; Yadetie et al. 1999). Several studies have been demonstrated an impairment of natural action of primary steroid hormones responsible for regulating gametogenesis including E2, androgens testosterone (T), and 11-ketotestosterone in fish collected from highly contaminated sites with alkylphenols or in fish after being exposed to nonylphenol ethoxylates (Sone et al. 2004; Rankouhi et al. 2004; Mitchelmore and Rice 2006). An increase in vitellogenin level in liver and blood of male common carp previously exposed to 4-NP has been also reported (Cardinali et al. 2004; Mitchelmore and Rice 2006). Moreover, histological alterations and lesions in reproductive organs as well as hepatic and kidney tissues have been reported in some fish species after being exposed to 4-NP (Weber et al. 2003; Zha et al. 2008; Yang et al. 2008). However, the harmful effects of 4-NP on fish reproductive system are still a controversial issue (Giesy et al. 2000; Matsumura et al. 2005; Yang et al. 2008).

This study aimed to investigate the effects of 4-NP as the biological breakdown product of widely used non-ionic surfactant on some reproductive parameters and histology of reproductive tissues in male and female of koi carp (Cyprinus carpio). As the HPG axis of this extensively farmed species is activated in small size (50-100 g), therefore, it is a good biological model for such physio-toxicological assays.

\section{Materials and methods}

Fish

One hundred and eighty apparently healthy immature koi carp including 90 females (55 \pm 0.5 g) and 90 males (54 $\pm 0.7 \mathrm{~g}$ ) were obtained from a local hatchery of an ornamental fish center (Tehran, Iran); and were transported to fisheries laboratory at Tehran Science and Research University. Fish were randomly divided into 18 glass aquaria $(100 \times 30 \times 50 \mathrm{~cm})$ with 10 fish per aquarium. Water quality condition (conductivity $400 \mathrm{~L} / \mathrm{min}$, pH 7.5, dissolved oxygen $5 \pm 0.2 \mathrm{mg} / \mathrm{L}$, temperature $23-24{ }^{\circ} \mathrm{C}$ and photoperiod of $12: 12 \mathrm{~h}$ light:dark) was maintained constant during the trail with a whole water exchange per day and fish were fed with a commercial carp pellet at $3 \%$ body weight/day and waste products were siphoned daily. The experiment was performed according to the standard guidelines for the care and use of experimental animals by Science and Research Branch University Committee (Collegiate Committee on Ethics Matched Biomedical Researchers, Tehran).

Exposure conditions

Branched chain isomers of 4-NP (CAS No. 84852-15-3 with purity > 95\%) and E2 (Sigma-Aldrich, Deisenhofen, Germany) were mixed with coconut oil (Sigma-Aldrich, Deisenhofen, Germany) and absolute ethanol (Merck, Darmstadt, Germany) as the chemical vehicle (Pait and Nelson 2003) to prepare treatment doses of 10, 50 and $100 \mu \mathrm{g} / \mathrm{g}$ body weight (BW) (Christensen et al. 1999; Yadetie et al. 1999; Casini et al. 2002; Carrera et al. 2007). E2 at $2 \mu \mathrm{g} / \mathrm{g}$ BW was also used as a separated treatment. Feeding was stopped $24 \mathrm{~h}$ prior to injection and ten fish per treatment were intraperitoneally injected with the mentioned dosages after 
being anesthetized with 2-phenoxyethanol at 0.1\% (Merck, Darmstadt, Germany). The positive control group (C2) received the vehicle $(50 \mu \mathrm{L}$ of coconut oil $+50 \mu \mathrm{L}$ Ethanol per fish) and a negative control group (C1) was considered without injection. Fish were injected on days 7, 14 and 21 after the initiation of the experiment.

Blood sampling

On day 22, the blood samples were collected from the caudal vein after fish being anaesthetized with clove oil $(150 \mathrm{mg} / \mathrm{L})$, and sera samples were separated by centrifugation at $3000 \times g$ for 10 min (SIGMA 3-30 K, Osterode am Harz, Germany) before being frozen at $-80^{\circ} \mathrm{C}$ until analysis. Fish were then dissected and separated by sex gonad characters.

Steroid hormones assay

Steroid hormone levels including E2, T, and P were measured using radio immune assay (RIA) kit (Immunotech, Marseille, France) and gamma counter (LKB-Wallac RackGamma, Turku, Finland). Samples and standards were incubated in monoclonal antibody-coated tubes with 125I-labeled tracer T, E2 and P (50 mL sample or standard and $500 \mathrm{~mL}$ of tracer). After one $\mathrm{h}$ incubation with horizontal shaking at $400 \mathrm{rpm}$, the liquid contents of the tubes were removed and the radioactivity bound to the antibody was measured by JNG 403 (Multichannel gamma counter for RIA). The samples were analyzed using two kits in two analyses' forms of the calibration curve $\left(r^{2}>0.98\right)$.

Vitellogenin assay

The plasma vitellogenin (VTG) concentration was determined in the sera samples of five females and 5 males (totally 10 fish) in each treatment. VTG concentration was detected using carp vitellogenin ELISA kit (Biosense Laboratories AS, Bergen, Norway) following manufacturer's instructions by an A3 plate reader (DAS, Rome, Italy) at $492 \mathrm{~nm}$. VTG concentrations were detected based on a standard curve developed from the absorbance values for VTG standards $\left(r^{2}>0.99\right)$.

\section{Histological study}

Five fish of each treatment were randomly removed and tissue samples of ovary, testis and liver were taken prior to be fixed in $10 \%$ neutral buffered formalin. The fixed tissues were processed for routine histotechnique, embedded in paraffin blocks before obtaining $5 \mu \mathrm{m}$ thickness sections by a Leica RM2255 microtome (Leica Microsystems, Germany). The obtained sections were stained with Harris's hematoxylin and eosin stain $(\mathrm{H} \& \mathrm{E})$, dehydrated through a graded alcohol series and mounted onto the glass slides (Bancroft and Stevens 1982) before being examined under light microscope (Olympus DP71, Tokyo, Japan).

\section{Transmission electron microscope (TEM)}

To evaluate TEM, the ovaries were cut into approximately $1 \times 1 \mathrm{~mm}$ piece, fixed in $3 \%$ glutaraldehyde and washed in cacodylate buffer prior to being fixed in $1 \%$ osmium tetroxide prepared in the same buffer for one $\mathrm{h}$ at $4{ }^{\circ} \mathrm{C}$. Specimens were then dehydrated in ascending grades of acetone with two changes of 15 min each after being cleared by propylene oxide for $30 \mathrm{~min}$. Infiltration was performed gradually in different proportion of propylene oxide with liquid resin. Tissue samples were embedded in the araldite embedding medium using BEEM $^{\circledR}$ capsules (BEEM Inc., Bronx, USA) before being incubated at 50 and $60{ }^{\circ} \mathrm{C}$ in an embedding oven for 24 and $48 \mathrm{~h}$, respectively, to complete polymerization. The obtained thin sections $(1 \mu \mathrm{m})$ were stained with toluidine blue before being used for examination under a light microscope. The ultrathin sections collected on copper grids were also stained with uranyl acetate followed by lead nitrate prior to examination under scanning electron microscopy (Oxford INCA 200, Oxford Instruments Group, High Wycombe, UK) at an accelerating voltage of $80 \mathrm{kV}$. 
Statistical analysis

Data were subjected to SPSS Version 16.0 for windows (SPSS Inc., USA), and checked for normal distribution (Shapiro-Wilk's test) and homogeneity of variances (Levene's test) using P-P plot analysis. One-way analysis of variance (ANOVA) followed by the NP exposure for each endpoint relative Duncan's test was used to examine the effect of the control group and significance was set at $P<0.05$.

\section{Results}

Steroid hormones

\section{Female}

The value of E2 in female fish received 10 and $50 \mu \mathrm{g}$ 4-NP were significantly $(P<0.05)$ higher than control groups (Fig. 1), while fish exposed to $100 \mu \mathrm{g}$ 4-NP showed significantly $(P<0.05)$ a lower value of E2 than both 10 and $50 \mu \mathrm{g}$ 4-NP treatments (Fig. 1). Also, the value of T was decreased with an increase in 4-NP dose $(P<0.05)$ with the lowest value obtained in fish treated with $100 \mu \mathrm{g} 4-\mathrm{NP}(P<0.05)$ (Fig. 1). Also, E2 value in E2-treated fish group was significantly lower than fish treated with 4-NP at $50 \mu \mathrm{g} / \mathrm{g} \mathrm{BW}$, while it increased to higher levels than 10 and $50 \mu \mathrm{g}$ 4-NP groups. Also, no significant difference was seen in the level of $\mathrm{P}$ between 10 and $50 \mu \mathrm{g}$ 4-NP groups, while this was significantly lower in the $100 \mu \mathrm{g}$ 4-NP group. No significant difference was seen in level of T between E2 treated fish and 4-NP treated with $100 \mu \mathrm{g} / \mathrm{g} \mathrm{BW}$ $(P<0.05)$, while T level in E2-treated fish was lower than 10 and $50 \mu \mathrm{g} / \mathrm{g} \mathrm{BW}$ groups. Also, E2 value in fish treated with $2 \mu \mathrm{g}$ E2 was significantly $(P<0.05)$ higher than control groups.

\section{Male}

The highest value of E2 was obtained in fish treated with 4-NP at $50 \mu \mathrm{g}$ compared to other groups and control ones $(P<0.05)$. Also, this value in fish treated with $2 \mu \mathrm{g}$ E2 was significantly higher than fish treated with 10

$$
\square \mathrm{P}(\mathrm{ng} / \mathrm{ml}) \quad \square \mathrm{T}(\mathrm{ng} / \mathrm{ml}) \quad \square \mathrm{E} 2(\mathrm{ng} / \mathrm{ml})
$$

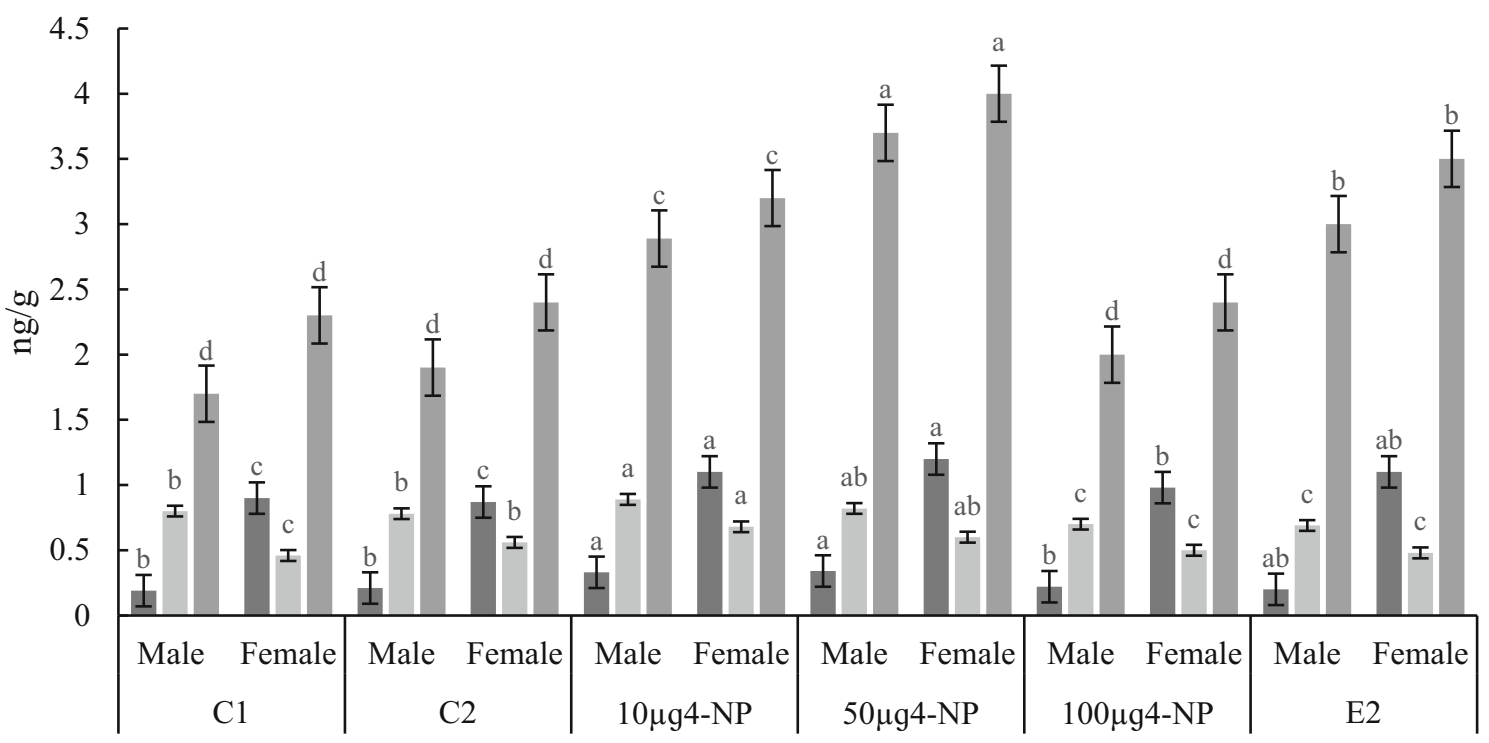

Fig. 1 Steroid hormones' changes in koi carp after 21 days exposure to different concentrations of 4-nonylphenol. E2, 17 $\beta$ Estradiol; T, testosterone; P, progesterone; $\mathrm{C}$, control 1; C2, control 2. Different letters indicate significant difference between experimental groups $(n=3, P<0.05)$ 
and $100 \mu \mathrm{g} 4-\mathrm{NP}(P<0.05)$ (Fig. 1). The concentration of E2 in fish treated with 10 and $50 \mu \mathrm{g} 4-\mathrm{NP}$ and $2 \mu \mathrm{g}$ E2 showed significantly a higher value than both control groups. In addition, the value of $P$ increased significantly $(P<0.05)$ with an increase in $4-\mathrm{NP}$ concentration up to $50 \mu \mathrm{g}$, but its concentration at $100 \mu \mathrm{g}$ 4-NP gave a significant decrease compared to both 10 and $50 \mu \mathrm{g}$ treatments (Fig. 1). No significant difference was seen in level of $\mathrm{P}$ among fish treated with $100 \mu \mathrm{g} 4-\mathrm{NP}, 2 \mu \mathrm{g}$ E2 and control groups $(P>0.05)$. Value of $\mathrm{T}$ in fish treated with 10 and $50 \mu \mathrm{g}$ 4-NP was significantly higher than fish treated with $100 \mu \mathrm{g} 4-\mathrm{NP}$ and $2 \mu \mathrm{g}$ E2. Also, this value in both fish treated with $100 \mu \mathrm{g} 4-\mathrm{NP}$ and $2 \mu \mathrm{g}$ E2 was significantly lower than control groups $(P<0.05)$.

Plasma vitellogenin

\section{Female}

The plasma VTG concentration was significantly higher in fish treated with 10 and $50 \mu \mathrm{g} 4-\mathrm{NP} / \mathrm{g} \mathrm{BW}$ compared to controls groups $(P<0.05)$. Also, fish received $100 \mu \mathrm{g}$ 4-NP significantly showed a decrease in VTG value compared to both 10 and $50 \mu \mathrm{g} 4$-NP trails $(P<0.05)$. Further, fish treated with $2 \mu \mathrm{g}$ E2 significantly gave an increase in VTG level compared to other groups (Fig. 2).

\section{Male}

A similar trend in plasma VTG concentration was observed in male fish (Fig. 2). VTG concentration significantly $(P<0.05)$ increased in fish treated with $10 \mu \mathrm{g} 4$-NP compared to control groups. Considerable elevations were also observed in plasma concentration of male fish exposed to $50 \mu \mathrm{g} 4-\mathrm{NP} / \mathrm{g}$ BW compared to other treatments $(P<0.05)$, but a significant decrease was observed in $100 \mu \mathrm{g} 4-\mathrm{NP}$ trail compared to both 10 and $50 \mu \mathrm{g}$ 4-NP trails (Fig. 2).

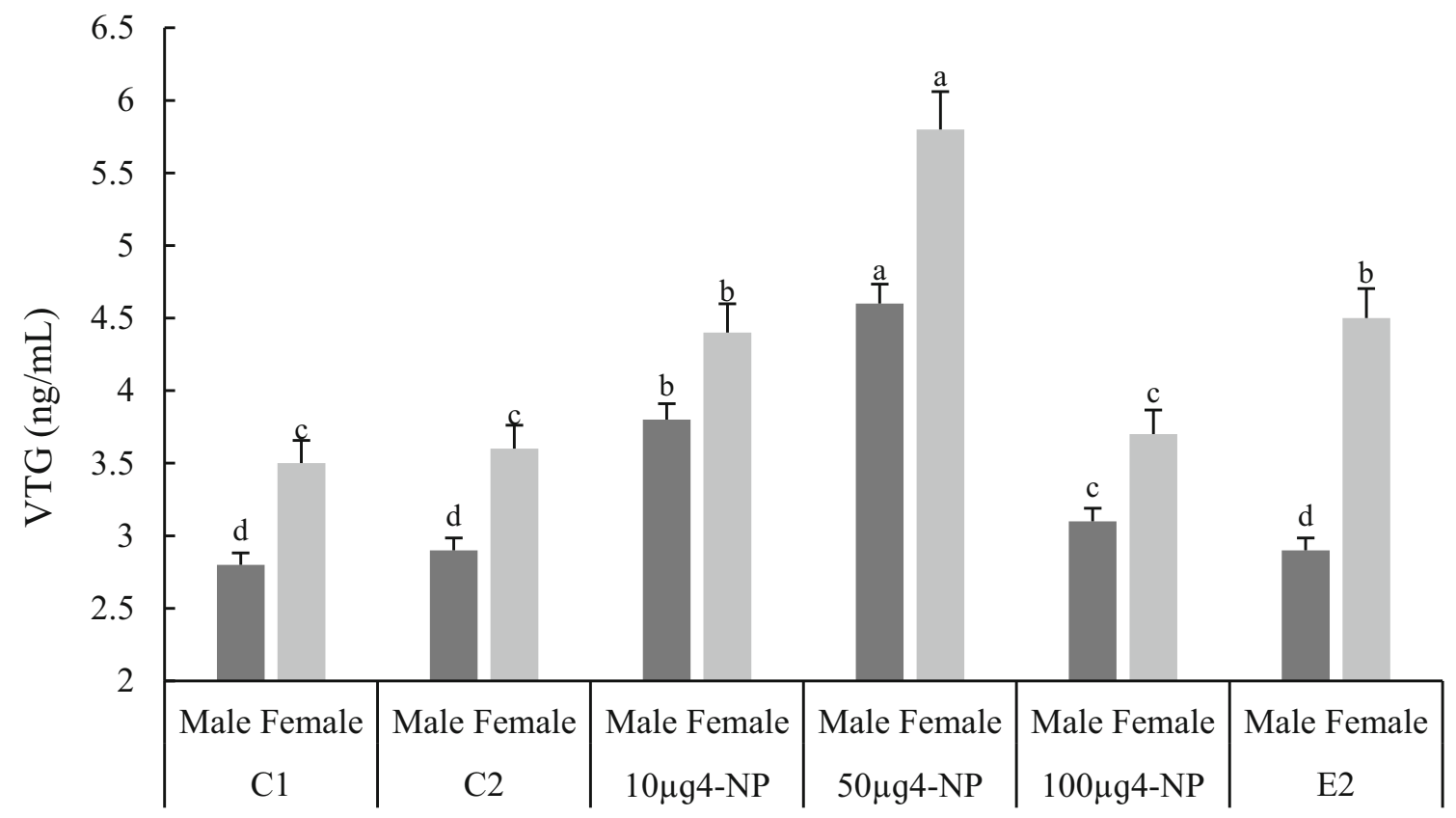

Fig. 2 Vitellogenin (VTG) changes in koi carp after 21 days exposure to different concentrations of 4-nonylphenol. Different letters indicate significant difference between experimental groups $(n=3, P<0.05)$ 
Female histological findings

No histological changes were seen in the ovaries of control fish (Fig. 3a, b). The ovary of female fish exposed to 10 and $50 \mu \mathrm{g}$ 4-NP was loaded with oocytes in different vitelogenic stages and late vitellogenesis (Fig. 3c, d). The vitellogenic oocytes contained normal yolk materials (fatty yolk globules and protein granules) and surrounded by zona radiate and follicular epithelium that consists of granulose cell layer and thecal layer. Fish exposed to $100 \mu \mathrm{g}$ 4-NP showed a reduction in size of the growing vitellogenic oocytes and ova damage including vacuoles (v), irregular shape of ovum with rupture of follicular layer and atretic (Fig. 3e, f). The number of follicular atretic after exposure to $100 \mu \mathrm{g}$ 4-NP was significantly increased compared to control fish (arrows). No histological change was seen in ovaries of control fish (Fig. 3a, b).

Necrosis, degeneration, psychosis, and cytoplasmic vacuolization of hepatic parenchyma were seen in the liver samples all treated fish (Fig. 4b, c) but with more severe histological changes observed in fish treated with higher dosage of 4-NP, i.e., $100 \mu \mathrm{g} / \mathrm{g} \mathrm{BW}$ (Fig. 4d). Also, liver samples of fish treated with $100 \mu \mathrm{g}$ 4-NP showed a sedimentation of cytoplasmic and an increase in cytoplasmic vacuolization (Fig. 4e, f).

\section{Ovary TEM}

No abnormality was seen in sections obtained from the control fish (Fig. 5a). Ovaries of female fish exposed to $10 \mu \mathrm{g}$ 4-NP showed an increase in size and number of previtellogenic oocytes and most of ova demonstrated a vitellogenesis stage containing droplets of fat and cortical alveoli. The external membrane presented a normal in shape having a higher amount of yolk particles. Yolk particles with a relatively high volume of pores and channels through the porous passing to the inner membrane and density of porous channels were also seen (Fig. 5b). In fish exposed to $50 \mu \mathrm{g} 4-\mathrm{NP}$, an increase in vitellogenesis with a remarkable increase in vitellogenin particles was observable. Outer membrane of the yolk particles with a relatively high volume of pore channels in passing to the inner membrane and making micro-pinocytosis cascade was seen (Fig. 5c, d). An abnormal external membrane with a few channels containing a little penetration of vitellogenin inside the internal membrane was also seen in fish exposed to $100 \mu \mathrm{g}$ 4-NP. Further, a decrease in number of channels with no transport of materials in this layer was observable (Fig. 5e, f).

Male histological findings

The testis of the control fish contained spermatids, spermatozoa, lumen space, seminiferous lobule, and interlobular connective tissue histological structure (Fig. 6a). In testis of fish exposed to $10 \mu \mathrm{g} 4-\mathrm{NP}$, a large extended sperm duct loaded with spermatozoa and seminiferous lobules with different amounts of spermatozoa, together with wide lumen free of spermatozoa, were detected (Fig. 6b). In fish exposed to 50 $\mu \mathrm{g} 4-\mathrm{NP}$, a discontinuous interlobular connective tissue with a reduction in testis mass was seen. Also, the seminiferous lobules were filled with spermatozoa or late spermatids (Fig. 6c). A decrease in spermatids and spermatozoa, degeneration of Leydig cells, atrophy of testis cells and cellular vacuolation were also observable in sections obtained from fish treated with $100 \mu \mathrm{g}$ 4-NP (arrows) (Fig. 6d).

\section{Discussion}

The results of the present work showed that 4-NP at 10 and $50 \mu \mathrm{g} / \mathrm{g} \mathrm{BW}$ was able to increase the concentrations of steroid hormones of E2 and P in both male and female koi carp, while the value of testosterone was reduced. However, these hormones' concentrations were reduced at the higher dosage, i.e., $100 \mu \mathrm{g} / \mathrm{g} \mathrm{BW}$. Hasselberg et al. (2004) showed that there is a reverse relationship between CYP1A and amount of estradiol in fish plasma in a way that CYP1A is effective in metabolizing steroids. In our study, a gradual increase in E2 of fish treated with 10 and $50 \mu \mathrm{g} / \mathrm{g}$ BW could be a reason for a decrease in the activity of metabolizing enzymes. Yang et al. (2008) reported similar results when goldfish (Carassius auratus) was exposed to 4-NP at $100 \mu \mathrm{g}$ 4-NP for 20 days. Also, a significant increase of E2 was seen in female fathead minnows (Pimephales promelas) after fish being exposed to 4-NP at $0.09 \mu \mathrm{g} / \mathrm{L}$ (Giesy et al. 2000). Lavado et al. (2004) demonstrated an inhibition in glucuronidation and sulfidation of sexual steroids in common carp exposed to NP. Thus, such 

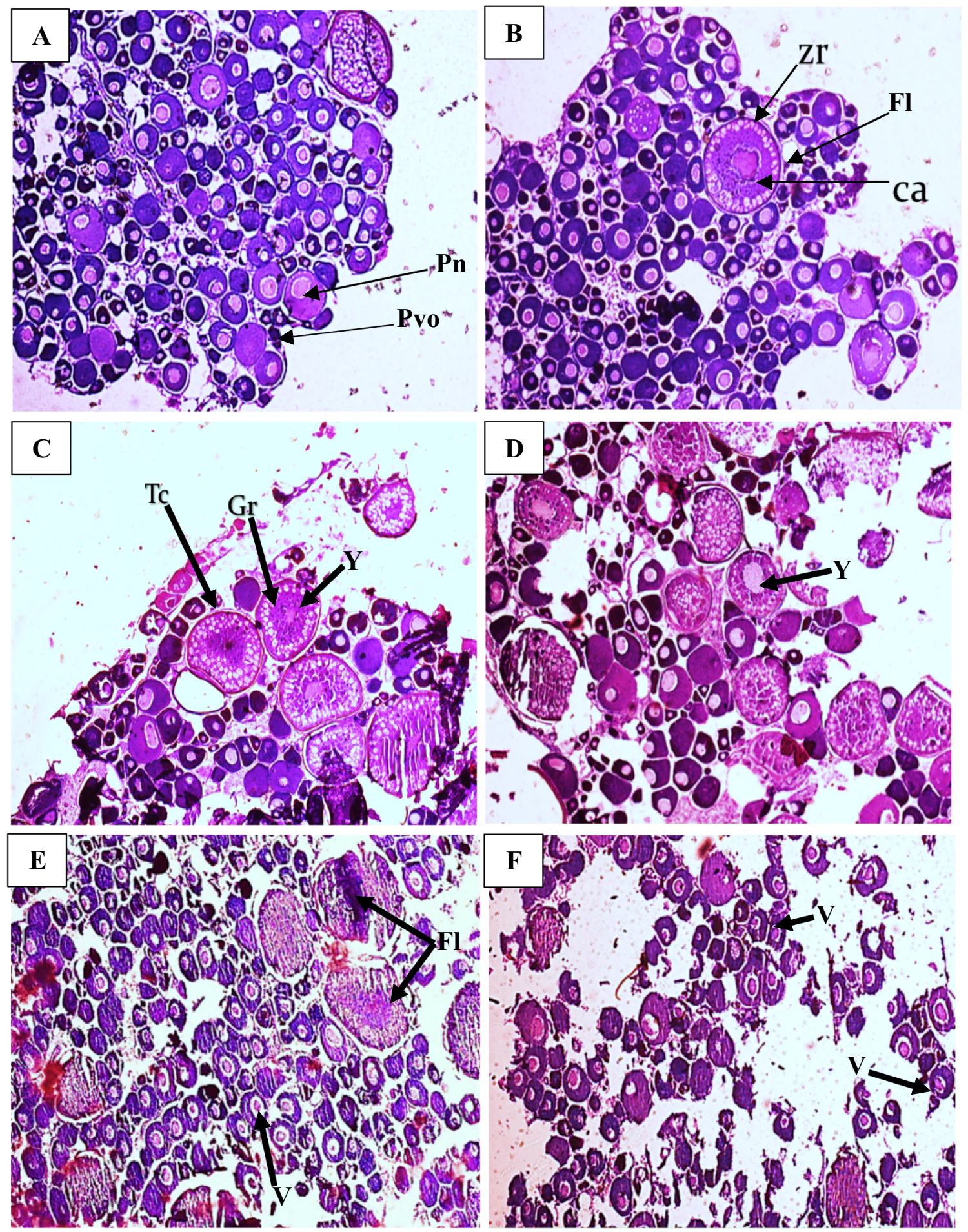

Fig. 3 Sections of koi carp ovary exposed to 4-nonylphenol at different concentrations. a control fish showing normal ovarian structures, b fish treated with $17 \beta$-Estradiol, c, $\mathbf{d}$ fish treated with 10 and $50 \mu \mathrm{g} / \mathrm{g} \mathrm{b}$ w, respectively; $\mathbf{e}, \mathbf{f}$ fish exposed to $100 \mu \mathrm{g}$ 4-NP/g BW (H\&E, ×400). Pvo, previtellogenic oocytes; Pn, peri-nucleolar; Fl, intact follicular layer; Zr, zona radiate; Ca, cortical alveoli; Gr, granulose cell layer; TC, thecal layer; Y, yolk; V, vacuolization

inhibition of glucuronidation and sulfidation in liver could be the cause of an increase in E2 seen in our work. However, when turbot (Scophthalmus maximus) was exposed to nonylphenol at $30 \mu \mathrm{g} / \mathrm{g}$ significantly, a decrease was occurred in the estradiol and testosterone levels as well as a reduction in the ovary aromatase enzyme and glucuronidation of sex steroids (Martin-Skilton et al. 2006). 

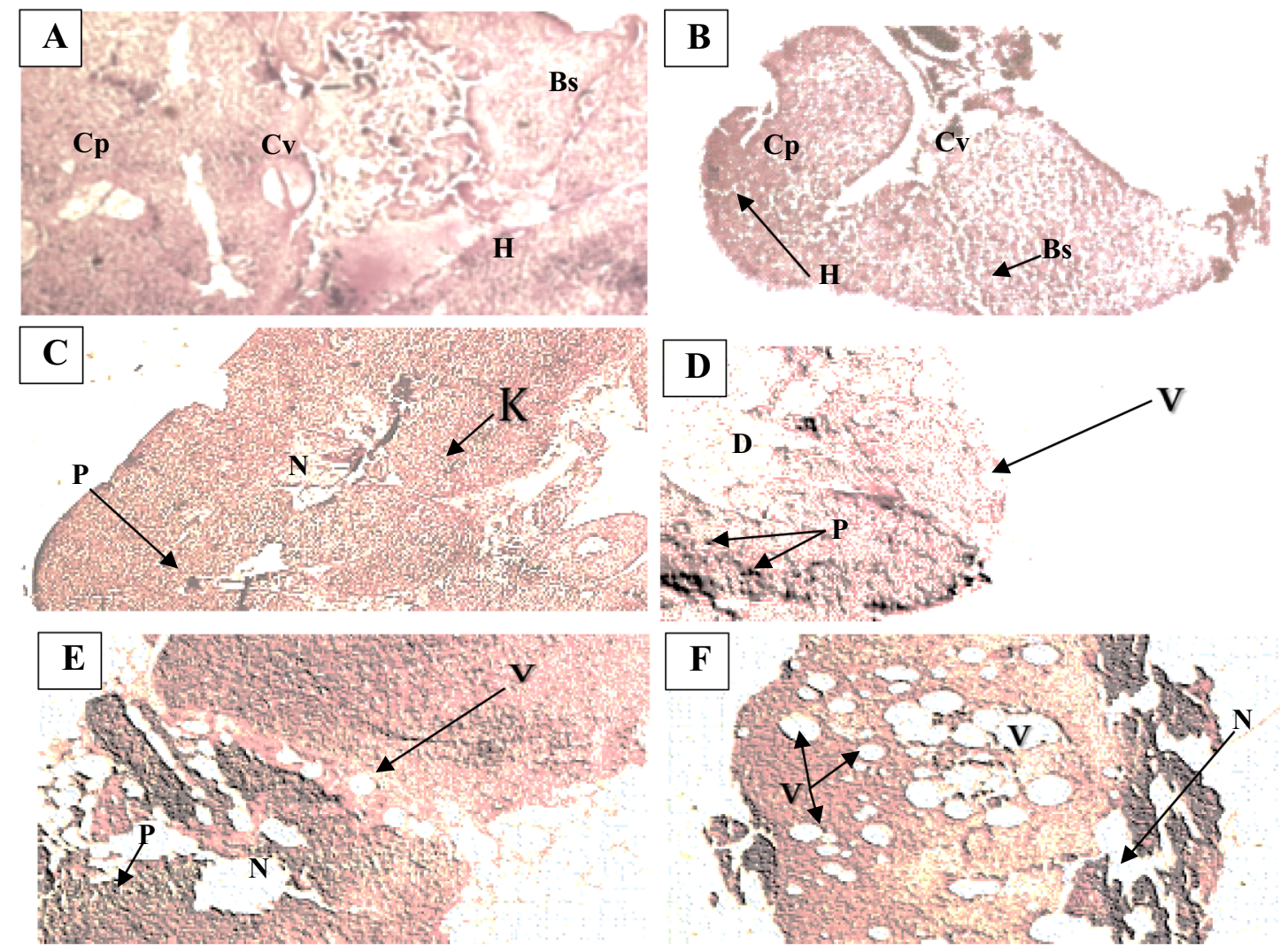

Fig. 4 Sections of koi carp liver exposed to different concentration of 4-nonylphenol. a Control fish showing normal histological structures, $\mathbf{b}$ fish treated with $17 \beta$-Estradiol, $\mathbf{c}, \mathbf{d}$ fish treated with 10 and $50 \mu \mathrm{g}$ 4-NP/g b w, respectively; e, $\mathbf{f}$ fish treated with $100 \mu \mathrm{g} 4-\mathrm{NP} / \mathrm{g}$ BW (H\&E, ×400). Cp, cytoplasm; Cv, central vein; Bs, blood sinusoids; H, hepatocyte; N, necrosis; K, Kupffer cell; D, degeneration; P, Pyknosis; V, vacuolation

Zenoestrogens like 4-NP can be accomplished by inhibitory effects in different sections of hypothalamushypophysis-gonads axis, and an effluence of the hormone receivers can cause a change in the secretion of hormones (Folmar et al. 2002; Lavado et al. 2004). Also, 4-NP could inhibit the activity of 17 alphahydroxylase enzymes which are involved in testosterone synthesis (Laurenzana et al. 2002). However, Villeneuve et al. (2002) have demonstrated no effect on E2, T and VTG in matured common carp male exposed to $4-\mathrm{NP}$ at $0.05-5.4 \mu \mathrm{g} / \mathrm{L}$ for $28-31$ days.

The plasma VTG in both male and female fish treated with $50 \mu \mathrm{g} / \mathrm{g}$ BW was significantly higher than control fish, whereas it significantly decreased at higher concentration, i.e. $100 \mu \mathrm{g} / \mathrm{g} \mathrm{BW}$ that may be in part due to a higher level of estrogen receptors on hepatocytes. Flouriot et al. (1995) demonstrated an increase in level of estrogen receptors and mRNA vitellogenin in hepatocyte cells of rainbow trout after fish being exposed to 4-NP at $10 \mu \mathrm{M}$. Therefore, 4-NP may play a role via estrogen receptors in a competition pathway with a much lower potent than E2 providing an estrogenic effect. Such similar function of 4-NP with E2 mimics to enhance the vitellogenin synthesize resulting in both hyperplasia and hypertrophy of hepatocytes in liver tissue (Arukwe et al. 1997).

Remarkable histological malformations were observed in ovaries of koi carp exposed to 4-NP, especially at the higher dosage. This could be in part due to 4-NP effect on oocytes and intrigue of gene expression of VTG as well as an increase in yolk formation and growth of ovary follicles. An increase in yolk production can cause a gathering vitellogenesis in oocytes with a consequence increasing in GSI index in female fish. In contrast, number of degenerated eggs and asteriated follicles in the ovary fish subjected to 4-NP at $100 \mu \mathrm{g} / \mathrm{g}$ BW showed a significant increase compared to other treatments. Degeneration of the cells of the follicular layer may cause a decrease in the level of synthesis of sexual steroids delaying the maturity of sexual cells and 

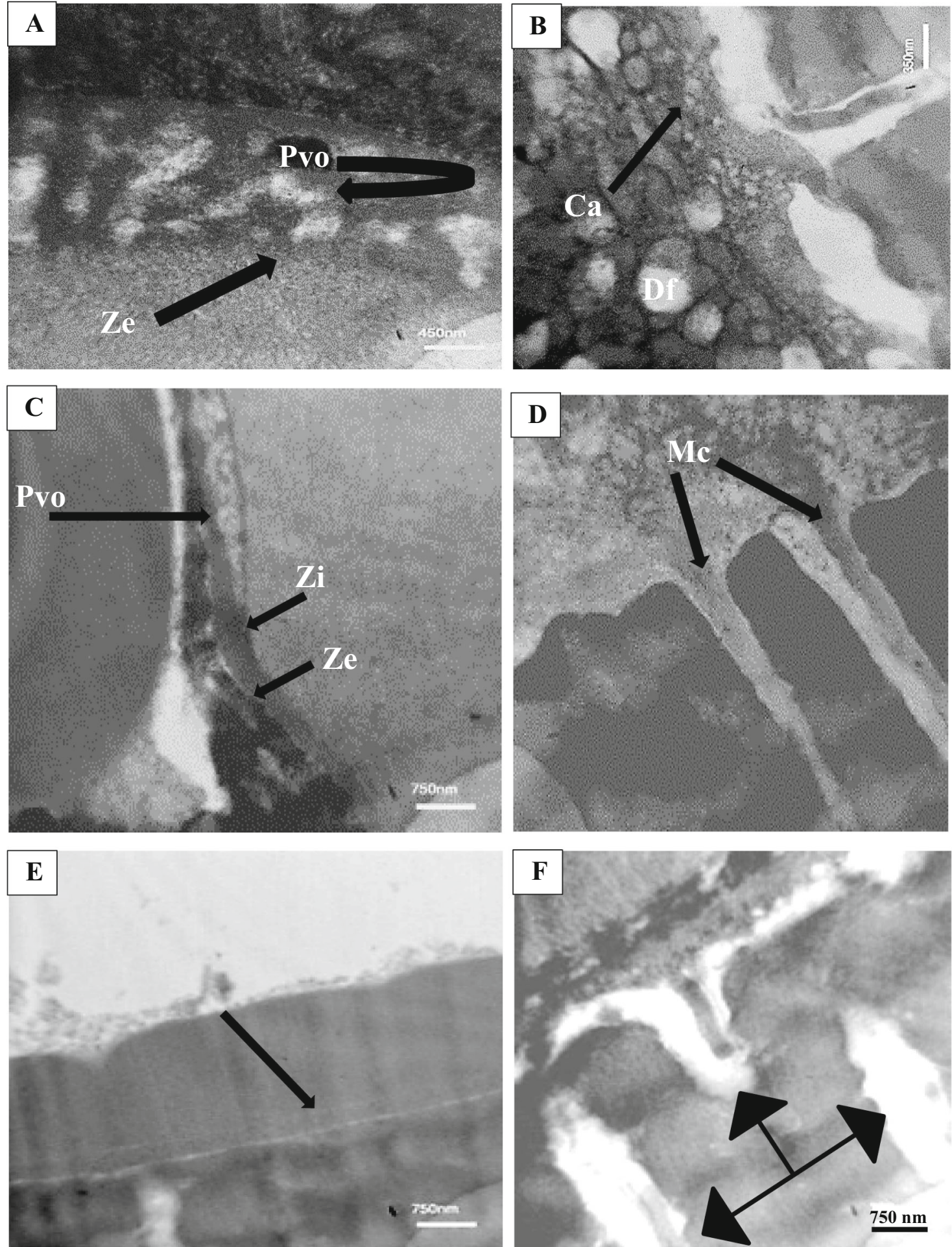

Fig. 5 Transmission electron micrograph of koi carp ovary treated with different concentration of 4-nonylphenol. a Control fish showing normal histological structures, b fish treated with $17 \beta$-Estradiol, $\mathbf{c}, \mathbf{d}$ fish treated with 10 and $50 \mu \mathrm{g} / \mathrm{g} \mathrm{BW}$, respectively, e, f fish treated with $100 \mu \mathrm{g} / \mathrm{g} \mathrm{b}$ w showing penetration of vitellogenin inside the zona internal ovary membrane (arrows). Pvo, previtellogenic oocytes; Ze, zona external membrane; Df, droplets of fat; Ca, cortical alveoli; Zi, zona internal membrane; Mc, micro-pinocytosis cascade 


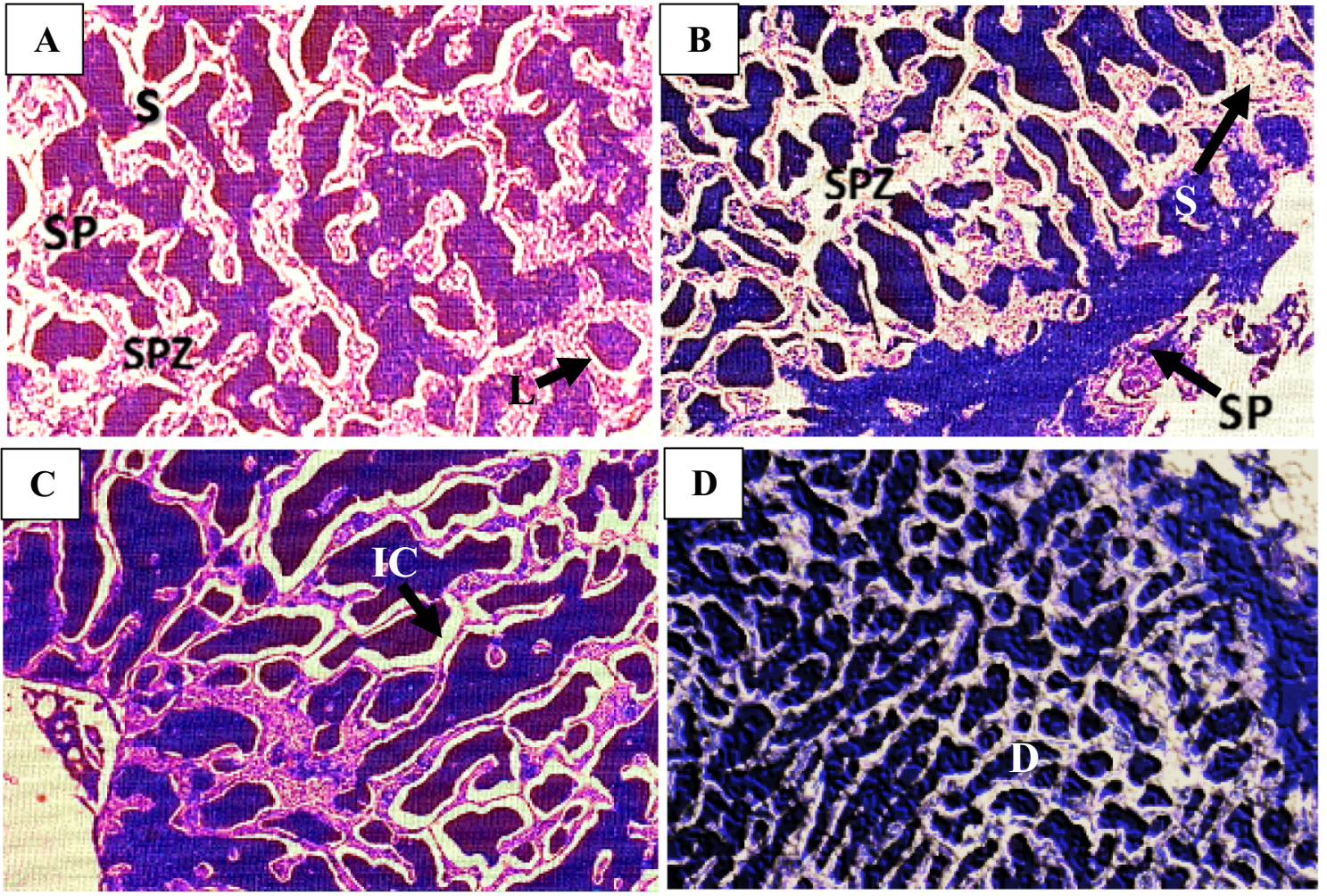

Fig. 6 Sections of koi carp testis treated with different concentrations of 4-nonylphenol. a Control fish showing normal histological structures, b-d fish treated with 10,50 and $100 \mu \mathrm{g} / \mathrm{g} \mathrm{BW}$, respectively $(\mathrm{H} \& \mathrm{E}, \times 400)$. SP, spermatids; SPZ, spermatozoa; L, lumen space; S, seminiferous lobules; IC, interlobular connective tissue; D, degeneration of Leydig cells

egg expansion. Holdway et al. (2008) reported that exposing fish to EDCs before the spawning can result in a change in reproduction behavior, decrease fecundity and sexual hormone excretion. Also, Sayed et al. (2014) demonstrated a structural pathology and function in Nile tilapia (Oreochromis niloticus) with a high decrease in gonadosomatic indexes, fecundity and oocyte diameter after fish being exposed to $100 \mu \mathrm{g} 4-\mathrm{NP}$. In addition, African catfish (Clarias gariepinus) subjected to $4-\mathrm{NP}$ at $0.1 \mathrm{mg} / \mathrm{L}$ showed a decrease in fertilization, egg hatching and fecundity as well as a remarkable reduction in incubation period, mortality and abnormality of embryos (Sayed et al. 2012). In the present study, liver histology of female koi carp exposed to 4-NP demonstrated several cellular disorders including degeneration, necrosis and vacuolation. It has been shown by Lee et al. (2003) that 4-NP is able to create such disorders in testicules structures. Also, similar histopathological signs have been also reported in different fish spices subjected to NP at different concentrations (Lee et al. 2004; Bhattacharya et al. 2008; Kaptaner and Ünal 2011). However, lower concentration of 4-NP can promote sexual glands preparatory phase in female catfishe (Heteropneustes fossilis) by ovulation and maturation of oocytes (Gautam et al. 2011). Therefore, NP at lower concentration can cause ovulation and maturation of oocytes, but at the higher concentrations a delay in maturation and growth of sexual glands together with a significant increase in atresia oocytes of stages 1 and 2 can be occurred.

\section{Conclusion}

In conclusion, the results of this study demonstrated that 4-NP can mimic to play a role as an estrogenic hormone in the sexual development, hepatotoxicity and gonado-toxicity in koi carp. Also, 4-NP demonstrated to induce vitellogenin production and interfere with fish gonadal maturation. Therefore, as a large volume of detergents containing 4-NP are currently discharged into aquatic ecosystems, a particular attention is required to avoid use of contaminated waters with 4-NP for aquaculture activities that can lead to failure in the propagation and rearing of both wild and commercial fish species. 
Acknowledgements Authors would like to thank Mr. Hamid Fathalian and Mr. Saeid Totoonchi Mashhor for their valuable assistance.

Author contributions PA conducted the experiment, collection and assembly of data, MS and HHS designed and supervised the study, MS wrote the manuscript and SPHS analyzed the data and assist in writing the manuscript.

\section{Compliance with ethical standards}

Conflict of interest The authors report no conflict of interest.

Open Access This article is distributed under the terms of the Creative Commons Attribution 4.0 International License (http:// creativecommons.org/licenses/by/4.0/), which permits unrestricted use, distribution, and reproduction in any medium, provided you give appropriate credit to the original author(s) and the source, provide a link to the Creative Commons license, and indicate if changes were made.

\section{References}

Arukwe A, Förlin L, Goksøyr A (1997) Xenobiotic and steroid biotransformation enzymes in Atlantic salmon Salmo salar liver treated with an estrogenic compound, 4-nonylphenol. Environ Toxicol Chem 16:2576-2583

Bancroft JD, Steven A (1982) Theory and practice of histological technique. Churdchil Livingstone, Edinburgh

Bhattacharya H, Xiao Q, Lun L (2008) Toxicity studies of nonylphenol on rosy barb (Puntius conchonious): a biochemical and histopathological evaluation. Tissue Cell 40:243-249

Cardinali M, Maradonna F, Olivotto I, Bortoluzzi G, Mosconi G, Polzonetti-Magni AM (2004) Temporary impairment of reproduction in freshwater teleost exposed to nonylphenol. Reprod Toxicol 18:597-604

Carrera EP, García-López A, del Río MDPM, Martínez-Rodríguez G, Solé M, Mancera JM (2007) Effects of 17 $\beta$-estradiol and 4-nonylphenol on osmoregulation and hepatic enzymes in gilthead sea bream (Sparus auratus). Comparative Comp Biochem Physiol C Toxicol Pharmacol 145:210-217

Casini S, Fossi MC, Mori G, Bjornstad A (2002) Vitellogenin induction in Cyprinus carpio treated with $17 \beta$-estradiol and 4-nonylphenol. Environ Monit Assess 75:235-239

Choi S, Lee CH, Park W, Kim DJ, Sohn YC (2010) Effects of shortened photoperiod on gonadotropin-releasing hormone, gonadotropin, and vitellogenin gene expression associated with ovarian maturation in rainbow trout. Zool Sci 27:24-32

Christensen LJ, Korsgaard B, Bjerregaard P (1999) The effect of 4-nonylphenol on the synthesis of vitellogenin in the flounder Platichthys flesus. Aquat Toxicol 46:211-219

Flouriot G, Pakdel F, Ducouret B, Valotaire Y (1995) Influence of xenobiotics on rainbow trout liver estrogen receptor and vitellogenin gene expression. J Mol Endocrinol 15:143-151

Folmar LC, Hemmer MJ, Denslow ND, Kroll K, Chen J, Cheek A (2002) A comparison of the estrogenic potencies of estradiol, ethynylestradiol, diethylstilbestrol, nonylphenol and methoxychlor in vivo and in vitro. Aquat Toxicol 60:101-110

Gautam GJ, Chaube R, Joy KP (2011) 4-Nonylphenol Impairs Ovarian Recrudescence and Induces Atresia in the Catfish Heteropneustes fossilis. Indian J Sci Technol 4:245-246

Giesy JP, Pierens SL, Snyder EM, Miles-Richardson S, Kramer VJ, Snyder SA (2000) Effects of 4-nonylphenol on fecundity and biomarkers of estrogenicity in fathead minnows (Pimephales promelas). Environ Toxicol Chem 19:1368-1377

Hasselberg L, Meier S, Svardal A, Hegelund T, Celander MC (2004) Effects of alkylphenols on CYP1A and CYP3A expression in first spawning Atlantic cod (Gadus morhua). Aquat Toxicol 67:303-313

Holdway DA, Hefferman J, Smith A (2008) Multigeneration assessment of nonylphenol and endosulfan using a model Australian freshwater fish, Melanotaenia fluviatilis. Environ Toxicol 23:253-262

John DM, House WA, White GF (2000) Environmental fate of nonylphenol ethoxylates: differential adsorption of homologs to components of river sediment. Environ Toxicol Chem 19:293-300

Kaptaner B, Ünal G (2011) Effects of 17 $\alpha$-ethynylestradiol and nonylphenol on liver and gonadal apoptosis and histopathology in Chalcalburnus tarichi. Environ Toxicol 26:610-622

Laurenzana EM, Weis CC, Bryant CW, Newbold R, Delclos KB (2002) Effect of dietary administration of genistein, nonylphenol or ethinyl estradiol on hepatic testosterone metabolism, cytochrome P-450 enzymes, and estrogen receptor alpha expression. Food Chem Toxicol 40:53-63

Lavado R, Thibaut R, Raldúa D, Martın R, Porte C (2004) First evidence of endocrine disruption in feral carp from the Ebro River. Toxicol Appl Pharmacol 196:247-257

Lee HJ, Chattopadhyay S, Gong EY, Ahn RS, Lee K (2003) Antiandrogenic effects of bisphenol A and nonylphenol on the function of androgen receptor. Toxicol Sci 75:40-46

Lee HB, Peart TE, Chan J, Gris G (2004) Occurrence of endocrine-disrupting chemicals in sewage and sludge samples in Toronto, Canada. Water Qual Res J Can 39:57-63

Maradonna F, Carnevali O (2007) Vitellogenin, zona radiata protein, cathepsin D and heat shock protein 70 as biomarkers of exposure to xenobiotics. Biomarkers 12:240-255

Martin-Skilton R, Thibaut R, Porte C (2006) Endocrine alteration in juvenile cod and turbot exposed to dispersed crude oil and alkylphenols. Aquat Toxicol 78:S57-S64 
Matsumura N, Ishibashi H, Hirano M, Nagao Y, Watanabe N, Shiratsuchi H (2005) Effects of nonylphenol and triclosan on production of plasma vitellogenin and testosterone in male South African clawed frogs (Xenopus laevis). Biol Pharm Bull 28:1748-1751

Mitchelmore CL, Rice CP (2006) Correlations of nonylphenol-ethoxylates and nonylphenol with biomarkers of reproductive function in carp (Cyprinus carpio) from the Cuyahoga River. Sci Total Environ 371:391-401

Pait AS, Nelson JO (2003) Vitellogenesis in male Fundulus heteroclitus (killifish) induced by selected estrogenic compounds. Aquat Toxicol 64:331-342

Rankouhi TR, Sanderson JT, Van Holsteijn I, Van Leeuwen C, Vethaak AD, Van den Berg M (2004) Effects of natural and synthetic estrogens and various environmental contaminants on vitellogenesis in fish primary hepatocytes: comparison of bream (Abramis brama) and carp (Cyprinus carpio). Toxicol Sci 81:90-102

Rivero CL, Barbosa AC, Ferreira MFN, Dorea JG, Grisolia CK (2008) Evaluation of genotoxicity and effects on reproduction of nonylphenol in Oreochromis niloticus (Pisces: Cichlidae). Ecotoxicol 17:732-737

Sayed AEDH, Mahmoud UM, Mekkawy IA (2012) Reproductive biomarkers to identify endocrine disruption in Clarias gariepinus exposed to 4-nonylphenol. Ecotoxicol Environ Saf 78:310-319

Sayed AEDH, Abdel-Aziz SH, El-Sayed AF, Zeid S (2014) Structural and functional effects of early exposure to 4-nonylphenol on gonadal development of Nile tilapia (Oreochromis niloticus): b-histological alterations in testes. Fish Physiol Biochem 40:1495-1507

Sone K, Hinago M, Kitatama A, Morokuma J, Ueno N, Watanabe H, Iguchia T (2004) Effects of 17ß-estradiol, nonylphenol, and bisphenol-A on developing Xenopus laevis embryos. Gen Comp Endocr 138:228-236

Uguz C, Iscan M, Ergüven A, Isgor B, Togan I (2003) The bioaccumulation of nonyphenol and its adverse effect on the liver of rainbowtrout (Onchorynchus mykiss). Environ Res 92:262-270

Villeneuve DL, Villalobos SA, Keith TL, Snyder EM, Fitzgerald SD, Giesy JP (2002) Effects of waterborne exposure to 4-nonylphenol on plasma sex steroid and vitellogenin concentrations in sexually mature male carp (Cyprinus carpio). Chemosphere 47:15-28

Vos JG, Dybing E, Greim HA, Ladefoged O, Lambré C, Tarazona JV, Brandt I, Vethaak AD (2000) Health effects of endocrinedisrupting chemicals on wildlife, with special reference to the European situation. Crit Rev Toxicol 30:71-133

Weber LP, Hill Jr RL, Janz DM (2003) Developmental estrogenic exposure in zebrafish (Danio rerio): II. Histological evaluation of gametogenesis and organ toxicity. Aquat Toxicol 63:431-446

Yadetie F, Arukwe A, Goksøyr A, Male R (1999) Induction of hepatic estrogen receptor in juvenile Atlantic salmon in vivo by the environmental estrogen, 4-nonylphenol. Sci Total Environ 233:201-210

Yang L, Lin L, Weng S, Feng Z, Luan T (2008) Sexually disrupting effects of nonylphenol and diethylstilbestrol on male silver carp (Carassius auratus) in aquatic microcosms. Ecotoxicol Environ Saf 71:400-411

Yaron Z, Gur G, Melamed P, Rosenfeld H, Elizur A, Levavi-Sivan B (2003) Regulation of fish gonadotropins. Int Rev Cytol 225:131-185

Zaccaroni A, Gamberoni M, Mandrioli L, Sirri R, Mordenti O, Scaravelli D, Sarli G, Parmeggiani A (2009) Thyroid hormones as a potential early biomarker of exposure to 4-nonylphenol in adult male shubunkins (Carassius auratus). Sci Total Environ 407:3301-3306

Zha J, Sun L, Spear PA, Wang Z (2008) Comparison of ethinylestradiol and nonylphenol effects on reproduction of Chinese rare minnows (Gobiocypris rarus). Ecotoxicol Environ Saf 71:390-399

\section{Publisher's Note}

Springer Nature remains neutral with regard to jurisdictional claims in published maps and institutional affiliations. 